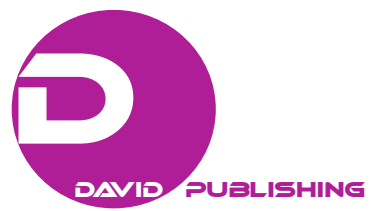

\title{
The Belt and Road Initiatives and China-GCC Relations*
}

\author{
Xuming QIAN \\ Shanghai International Studies University, Shanghai, China
}

\begin{abstract}
Gulf Cooperation Council (GCC) countries are the main countries of the West Asia, they are rich in oil and natural gas, and very important in the world political and economic arena. In recent years, the trade volume between China and six GCC countries has been rising. The paper analyzes the importance and the prospect of China-GCC Free Trade Area negotiations. The two sides should take positive action to further close dialogue mechanism between the two sides, restart the negotiations on the free trade zone between China and GCC countries as soon as possible, and reach a win-win agreement.
\end{abstract}

Keywords: GCC, China-GCC trade relations, China-GCC Free Trade Area negotiations, energy cooperation

\section{Introduction}

The Cooperation Council for the Arab States of the Gulf is the most important political and economic organization of the Gulf region, referred to as GCC. The GCC is located in the west end of Asia, with a total area of 2.67 million square kilometers, and a population of about 34 million, and is an important regional organization in the Middle East. The GCC member states are the main countries of the West Asia, they are rich in oil and natural gas, and have occupied a certain position in the world political and economic arena. Historically, this area was the access to the Silk Road, and the six GCC countries are the strategic focus areas of "The Belt and Road"; in recent years, bilateral trade volume between China and six GCC countries has been rising.

\section{Present Situation and Development of China's Economic and Trade Relations With the GCC}

The GCC was founded in May 1981, headquartered in the capital of Saudi Arabia, Riyadh. Its member states include six countries: the United Arab Emirates, Oman, Bahrain, Qatar, Kuwait, and Saudi Arabia. At present, the proven oil reserves of the GCC countries account for about $29.3 \%$ of world oil reserves ${ }^{1}$. Among the world's 10 largest oil producing countries, the GCC countries accounted for three, in addition to Bahrain, the proven oil reserves of the other five countries of the GCC ranked the world top 30. Saudi Aramco has become the largest oil company in the world, according to a report by the Petroleum Intelligence Weekly ${ }^{2}$.

China and the Gulf region locate in the East and West ends of Asia, respectively, but the ancient Silk Road links both sides together, and their friendly exchanges have a long history. In the new century, based on mutual

\footnotetext{
* Acknowledgement: Supported by Shanghai Peak Discipline Program (Class I): Foreign Language and Literature, and Sponsored by Shanghai Pujiang Program.

Xuming QIAN, Associate Professor, Middle East Studies Institute, Shanghai International Studies University.

1 Based on British Petroleum (BP) data.

2 Petroleum Intelligence Weekly Top 50. Retrieved from http://www2.energyintel.com/1/19202/2014-11-18/gp3qp
} 
respect and win-win cooperation, bilateral relations between China and the Arab have developed by leaps and bounds. The two sides have experienced the international changes, financial crisis, and the serious turmoil in certain countries of the region, and become a strategic partner of each other.

The traditional primary oil export market for GCC countries is the western countries. At present, the western countries, especially the United States, are vigorously promoting the diversification and development of alternative energy sources of oil, with the large-scale exploitation of shale gas, so their reliance on the GCC oil is relatively reduced. The GCC countries need to increase efforts to develop new markets, and they have the urgent need to deepen energy cooperation with China. China has signed long-term contracts on the establishment of the import of crude oil with Saudi Arabia, Oman, Yemen, Qatar, the United Arab Emirates, and other countries. The establishment of the free trade area between China and GCC will help the GCC with a stable oil export market, to ensure oil security of the GCC.

China and the GCC have strong economic complementarity, and a long history of economic and trade exchanges; their pragmatic cooperation has achieved remarkable results. The GCC countries mainly export oil and gas products to China; China mainly exports electromechanical products, and textile products etc. to the GCC countries. Saudi Arabia is the most significant trading partner of China in West Asia and Africa, and it is also the largest supplier of crude oil.

The leading industries of the Gulf countries are the petroleum industry and the petrochemical industry. Other heavy and light industries are less developed. The agricultural machinery, industrial equipment, and building materials, which are necessary for economic construction, need to be imported. With the rapid economic growth, China has become a "world factory" and its needs on the external market and resource have become more urgent. China has become the world's first energy consumer, and the second oil importing countries, providing a huge export market for the GCC countries for oil and petrochemical products.

In recent years, with the rapid development of China's economy, China's oil consumption is increasing, and the dependence on foreign energy is rising - has now risen to 57\% (China Daily, 2012). Among China's 10 largest sources of crude oil imports, four of them are the GCC countries. Saudi Arabia is China's largest source of crude oil imports. In 2009, China imports crude oil of 41.86 million tons from Saudi Arabia, accounting for $20.55 \%$ of the total imports of crude oil of China. In 2012, China's imported crude oil from Saudi Arabia grew to 53.916 million tons, an increase of $7.24 \%^{3}$. The GCC has important strategic significance on China's oil import. The establishment of the China-GCC Free Trade Area (FTA) will build a new platform for energy diplomacy between China and GCC countries, which is beneficial for China to obtain a stable supply of energy to ensure oil security.

The GCC countries are all single-product economies, and their industrial products and daily life commodities are dependent on imports. In recent years, unrest in East and North Africa has not had a huge impact on the economic and trade relations between China and the GCC, mainly due to the following aspects: firstly, for GCC countries, their national economic strength is relatively strong; with mutual political support, their political situation is relatively stable. Secondly, China's exports to the GCC are mainly products for the basic necessities of life; the price elasticity of demand is small, thus the demand is relatively stable. Thirdly, thanks to the accumulation of a large number of petro dollars, the governments of GCC countries have the ability to implement macro-control, including construction and transformation in industry and transportation,

\footnotetext{
${ }^{3}$ Retrieved from http://www.askci.com/news/201301/30/301011058454.shtml
} 
communications, and other municipal infrastructure .

In recent years, China and GCC countries' economic and trade relations have developed rapidly, with the proportion of the import and export between the two sides in their total foreign trade rising. From 1999 to 2004, bilateral trade volume between China and GCC countries achieved an average annual growth rate of over 40\%; in 2004, bilateral trade amounted to $\$ 24.736$ billion $^{4}$. From 2004 to 2008 , the GCC was the eighth largest trading partner of China for five consecutive years. In 2011, trade volume between China and the GCC amounted to $\$ 133.8$ billion, accounting for $68.3 \%$ of the total bilateral trade (Cheng, 2012). In 2012, trade volume between China and six GCC countries amounted to $\$ 155$ billion, accounting for nearly $70 \%$ of China's trade with the whole Arab region (BAI, ZUO, \& TANG, 2013). In 2015, China's trade volume with GCC countries reached $\$ 136.8$ billion, accounting for $70 \%$ of the total trade between China and Arab countries. China's total imports of crude oil from the GCC countries reached 110 million tons, accounting for nearly $75 \%$ of China's crude oil import from Arabia countries. As of the end of 2015, the signing of the labor contract between China and the GCC reached $\$ 102.8$ billion, and the non-financial mutual investment of the two sides amounted to $\$ 8.6$ billion (ZHENG, 2016).

The capital cooperation between China and the GCC countries includes mutual investment, project contracting, labor cooperation, and design consultation etc. In recent years, the bilateral capital cooperation between the two sides have become more close, and shows a good momentum of development; the direct investment to China from the GCC has been increasing year by year. In 2008, the GCC's direct investment in China amounted to $\$ 371.73$ million; in 2010 , this direct investment amounted to $\$ 596.8$ million; affected by the changes in the Middle East, in 2011, GCC's direct investment to China was reduced to $\$ 96.32$ million.

Chinese direct investment to the GCC is also growing. From 2003 to 2010, Chinese direct investment to the GCC increased from $\$ 10.66$ million to $\$ 1.675$ billion - increased by about 156 times in just seven years. China's direct investment stock to the GCC grows very rapidly, with the growth rate of more than $50 \%$. In 2011, Chinese direct investment to GCC amounted to $\$ 2.2275$ billion.

The GCC countries have accumulated a huge amount of oil dollar over the years; in recent years, they have advanced their foreign direct investment, and actively carry out overseas investment promotion and attraction at the same time. In order to achieve rapid economic diversification, and to reduce dependence on international oil market, the GCC countries have implemented economic diversification strategy to increase the proportion of non-oil industry. The GCC countries welcome Chinese enterprises to make investment, and provide convenient conditions for the Chinese capital. China has also formulated a series of preferential policies to attract foreign investment, optimized the structural adjustment in the field of investment, and launched a large-scale oil exploitation projects, which creates the conditions for GCC countries' expansion of investment in China (Meng, 2010, p. 29). China and the GCC have a great potential in the field of investment cooperation, and the establishment of a free trade area between China and the GCC will greatly enhance the scale and level of bilateral trade and investment between the two sides.

The project contracting and labor cooperation between China and GCC countries have been developing rapidly. In recent years, in order to promote the diversification of economic structure, the GCC countries have been implemented a large number of transportation, communications, infrastructure construction, special

\footnotetext{
${ }^{4}$ Chinese Embassy in Saudi Arabia, "China and the Gulf Cooperation Council carry out the first round of FTA negotiations", April 25, 2005. Retrieved from http://wcm.fmprc.gov.cn/pub/chn/pds/wjdt/zwbd/t438846.htm
} 
economic zones, and other development projects; and China is vigorously implementing the strategy of "going out". It has a strong ability of contract and the advanced experience, which leads to the continuous increase of the bilateral engineering investment. Labor cooperation is another highlight of bilateral economic and trade cooperation. The GCC countries generally lack of management personnel and skilled labor force, while China is rich in human resources. The two sides in the field of labor cooperation have great potential for development. In 2011 Chinese contracted projects turnover to the GCC countries amounted $\$ 8.68926$ billion. So far, Chinese companies have signed a contract of $\$ 71.3$ billion, covering housing, road and bridge construction, ports, power plants, telecommunications, and other fields (ZHANG \& YANG, 2013).

\section{China-GCC Free Trade Area Negotiations}

Shortly after the founding of the GCC, China established relations with it. Since the beginning of 1990, Foreign Ministers of China have been meeting with the Foreign Secretaries of the six GCC countries and the GCC Secretary General every year by the opportunity to attend the UN General Assembly. In 1996, China and GCC established economic and political consultation mechanism. In July 2004, the GCC Secretary General and Ministers of Finance of six GCC countries visited China together; China and the GCC signed the "Economy, trade, Investment and Technology Cooperation Framework Agreement", and announced the start of negotiations to establish a free trade area. From 2004 to 2006, China and the GCC carried out four rounds of negotiations, then for various reasons, negotiations were interrupted. In June 2009, the two sides restarted negotiations in the free trade zone in Saudi Arabia. So far, they have reached a consensus in the field of trade in goods negotiations in most areas, and have started negotiations on trade in services. The economic and trade cooperation between the two sides have made great progress. In 2013, bilateral trade volume reached $\$ 177$ billion, and Chinese enterprises signed a series of new labor contract which amounted to $\$ 10$ billion in the GCC countries. China's direct investment in the GCC countries amounted to $\$ 850$ million, and the actual use of investment from the GCC countries was $\$ 120$ million. In 2013, total direct investment from China to GCC reached four billion dollars, and the actual investment of the GCC to China amounted to \$2.7 billion. The GCC has become the largest source of crude oil imports of China, and China has also become one of the largest trading partners of the GCC countries. The cooperation of two sides in the field of finance, aviation, new energy, tourism, and other areas also presents rapid development momentum, showing great potential.

On June 4, 2010, the first session of the ministerial meeting of the strategic dialogue between China and GCC was held in Beijing. The two sides stressed on their readiness to continue to strengthen cooperation in various fields; the two sides signed the "Memorandum of Understanding on the Strategic Dialogue between People's Republic of China and Cooperation Council for the Arab States of the Gulf" (WANG, 2010). On May 2nd, 2011, the second session of the China-GCC strategic dialogue was held in Abu Dhabi. The two sides agreed that an expert meeting should be held as soon as possible, to form the action plan for the implementation of the Framework Agreement and the Memorandum of Understanding in the field of trade and investment, energy, culture, education, scientific research, environmental, health, and other fields, and to settle down the specific timetable. The two sides agreed to continue to strengthen consultations to complete the free trade area negotiations as soon as possible (AN, 2011).

On January 17, 2014, the third round of China-GCC strategic dialogue was held in Beijing. Chinese Foreign Minister WANG Yi and First Deputy Prime Minister \& Foreign Minister of Kuwait - then GCC presidency-Sabbah co-chaired the meeting. The GCC Secretary General Abdullatif bin Rashid Al-Zayan, the 
Foreign Minister Assistant of Qatar (the presidency of GCC) Mohammed Rumaihi, and other representatives of Ministry of Foreign Affairs of GCC members attended the meeting ${ }^{5}$. The two sides discussed relations between China and GCC and how to deepen and develop the relations in various fields; they also discussed international and regional issues of common concern. Both sides expressed satisfaction with the progress made in bilateral relations between China and GCC since the second round of strategic dialogue; they reviewed the fruitful cooperation between the two sides. The two sides agreed to be committed to the establishment of China-GCC is strategic partnership, believing that to strengthen bilateral dialogue and mutual trust, and to enhance the level of bilateral cooperation, are in line with the common interests of both sides; they are willing to continue efforts to deepen bilateral friendly relations and cooperation under the framework of dialogue mechanism. The two sides agreed and signed the "Action Plan on national strategic dialogue between People's Republic of China and the GCC 2014-2017", identifying cooperation target of the two sides in the politics, economy, energy, environmental protection and climate change, culture, education, health, sports, and other fields. The two sides stressed to accelerate negotiations of China-GCC FTA, sharing the view that China and GCC countries have strong economic complementarities, and the establishment of a free trade area is in line with the common interests of both sides. The two sides agreed that due to the strategic importance of the Gulf region in the Middle East, maintaining peace and stability in the region is in line with the common interests of the region and the international community. The two sides agreed to hold the fourth round of strategic dialogue between China and GCC in Qatar in 2005 (Chinanews.com, 2014).

In January 2016, President XI Jinping met with the Secretary General of GCC Abdullatif bin Rashid Al-Zayanduring during his visit to Saudi Arabia. He put forward his wish that the two sides would gather more common points to promote mutually beneficial cooperation and to benefit more people. China may become a long-term stable and reliable energy supply market for the GCC countries, and build on the full range of upstream and downstream energy cooperation pattern. China welcomes to restart negotiations on China-GCC FTA, and is in support of the efforts of GCC countries to maintain regional peace and stability. We hoped that the countries of the region would build and share the peaceful development of the Middle East and the Gulf through dialogue and cooperation in the spirit of mutual respect, non-interference in each other's internal affairs and good neighborly relations (DING, 2016). During President XI Jinping's state visit to Saudi Arabia, the two sides announced the resumption of China-GCC FTA negotiations, which had been suspended for as long as six years. According to the consensus, the two sides have held the sixth, seventh, and the eighth round of talks in Saudi Arabia, Guangzhou, China, and Beijing in February, May, and October, respectively (ZHENG, 2016).

On December 19-21, 2016, the ninth round of negotiations of China-GCC FTA was held in Riyadh of Saudi Arabia. China's Vice Minister of Commerce WANG Shouwen and GCC FTA Negotiations Coordinator $\&$ Saudi Arabia Vice Minister of Finance Baz led a delegation to attend the meeting. The two sides exchanged in-depth views on trade in services, investment, e-commerce, and other issues of trade in goods (ZHENG, 2016).

\section{Strategic Docking of "The Belt and Road" Initiative and the GCC}

In 2013, President XI Jinping proposed the establishment of "Chinese Silk Road Economic Belt" and "21st Century Maritime Silk Road strategy", which provides a new prospect for China to enhance the

\footnotetext{
5“"The third round of China-GCC strategic dialogue was held in Beijing”, Chinese Ministry of Foreign Affairs website. Retrieved from http://www.fmprc.gov.cn/mfa_chn/zyxw_602251/t1120026.shtml
} 
cooperation development, creating new opportunities for mutual benefit and win-win, which is a new engine in the new period to enhance cooperation between the two sides. "Belt and Road Initiative" strategy has also received widespread attention and positive response in the Gulf countries.

In January 2014, when President XI Jinping met with the delegation of the GCC, he said, since the China and GCC established relations, sustainable and healthy development of bilateral relations had been seen. The two sides were close friends, good friends, good partners with political mutual trust, economic and trade cooperation, and cultural exchanges. China would develop long-term friendly relations with the GCC as in the past. The two sides should strengthen planning and design, highlight the focus of cooperation, and enrich the connotation of cooperation. China was willing to work together with the GCC to promote the Silk Road Economic Belt and the construction of the Maritime Silk Road in 21st century (LI, 2014). After that, during Saudi Arabia Crown Prince Saleman and the Prime Minister of Kuwait's visit to China, to jointly build "The Belt and Road" was an important topic of discussion, and the both side made positive response. At the beginning of June 2014, the sixth Ministerial Meeting of the China-Arab Cooperation Forum was held in Beijing. During the meeting, President XI Jinping put forward the principle of "the two sides to consult, jointly build and share", cooperating to build "The Belt and Road initiative", and put forward the " $1+2+3$ " pattern of Sino-Arab cooperation. " 1 " refers to the energy cooperation as the main axis, to deepen cooperation in the full chain of oil and gas industry, maintaining security of energy transport channel, and building mutually beneficial, safe and reliable, long-term friendly strategic cooperation between China and Arab states. "2" refers to the construction of infrastructure, trade and investment facilitation as the two wings, to strengthen cooperation on major development projects and the iconic livelihood projects, with the establishment of relevant institutional arrangements to promote bilateral trade and investment. "3" is the breakthrough in the field of nuclear energy, aerospace, new energy, to strive to enhance the level of pragmatic cooperation between China and the Arab. In terms of cooperation in high-tech fields, President XI proposed the cooperative idea of three centers, namely, to discuss the establishment of the China-Arab technology transfer center, to build a research and training center for Arabia peaceful use of nuclear energy, and China Beidou Satellite Navigation System landing project in Arabia (DU \& JIAO, 2014).

Clearly, in the various cooperation proposed by President XI Jinping, the Gulf countries are in an important position, and there is great potential for cooperation between the two sides. Cooperation to build "The Belt and Road" has become the mainstream of China's cooperation with the Gulf countries under the new situation. It will promote cooperation in bilateral economy and trade, energy, infrastructure construction, high-tech, and other fields to a new level. China is willing to dock itself with the future development of the

Gulf countries, dock the capacity advantages of China and Arabia national comparative advantage, improve the layout of the opening-up of China and at the same time, bring the Gulf countries more stable energy yield, better facilities, more advanced level of science and technology, to achieve the common development and prosperity. China and the GCC to jointly build "The Belt and Road" will lead the future development of bilateral strategic cooperative relations, add vitality to bilateral relations and enhance driving power (WU, 2015).

\section{Conclusion}

Though China and GCC countries are facing different difficulties, there is a huge space for cooperation for the two sides. The GCC countries are the world's largest capital exporters, with two trillion dollars of capital 
outflow all over the world; the Gulf countries have the most abundant oil reserves in the region, and oil mining and processing of petroleum are still dominant in the Gulf countries' economic activities; more than half of the employment population are still in oil production department. The six countries of the Gulf are an important engineering contracting market in the Middle East, and also an important labor market in the world. After joining World Trade Organization (WTO), China made efforts to adapt to the international economic exchanges in the rules of the game, and "win-win" has become a principle for China in foreign economic activity, which lays a solid foundation for cooperation with the GCC countries.

\section{References}

AN, J. (2011, May 03). China and GCC held the second round of strategic dialogue. xinhuanet.com. Retrieved from http://news.xinhuanet.com/2011-05/03/c_121370255.htm

BAI, C., ZUO, J., \& TANG, Y. (2013). The opening of the China-GCC States Economic and Trade Cooperation Forum. xinhuanet.com. Retrieved from http://www.nx.xinhuanet.com/2013-09/17/c_117405856.htm

CHENG, C. (2012, August 02). ZHANG Yansheng: Three steps for China-GCC development and cooperation. China Industry and Economy News, A03.

China Daily. (2012, October 24). White paper on China's energy policy (2012). Information Office of the State Council. Retrieved from http://www.chinadaily.com.cn/china/2012-10/24/content_15843745.htm

Chinanews.com. (2014, January 17). Press communique on the third round of strategic dialogue between China and the GCC. Retrieved from http://www.chinanews.com/gn/2014/01-17/5751728.shtml

DING, L. (2016, January 23). President XI Jinping's visit to open a new era of Middle East cooperation with China, and China-GCC FTA negotiations will speed up. China Industry and Economy News, E002.

DU, S. Z., \& JIAO, X. (2014, May 06). XI Jinping attended the opening ceremony of the Sixth Ministerial Conference of the China-Arab Cooperation Forum and delivered an important speech. People's Daily, E01.

LI, W. H. (2014, January 18). XI Jinping met with the delegation of the GCC. People's Daily, E01.

MENG, C. (2010). Analysis on the economic effects of the free trade area between China and the Gulf Cooperation Council (Master thesis, Ocean University of China, 2010).

WANG, H. H. (2010). China and GCC held the first round of strategic dialogue. People's Daily, E03.

WU , S. K. (2015). Belt and Road Initiative under the framework of the China-GCC strategic cooperation. Arabia World Study, 2, 11.

ZHANG, L., \& YANG, J. (2013, September 16). China and GCC countries promote pragmatic cooperation and pursue a win-win situation. xinhuanet.com. Retrieved from http://news.xinhuanet. com/fortune/2013-09/16/c_117387538.htm

ZHENG, Q. T. (2016, December 22). China-GCC FTA is expected to reach an agreement this year. Twenty-first Century Economic Report, E05. 